\title{
Economic and Sustainability of Biodiesel Production-A Systematic Literature Review
}

\author{
Tamás Mizik $^{1, * \mathbb{D}}$ and Gábor Gyarmati ${ }^{2}$ \\ 1 Agribusiness Department, Corvinus University of Budapest, Fővám tér 8, 1093 Budapest, Hungary \\ 2 Keleti Faculty of Business and Management, Óbuda University, 1084 Budapest, Hungary; \\ gyarmati.gabor@kgk.uni-obuda.hu \\ * Correspondence: tamas.mizik@uni-corvinus.hu
}

Citation: Mizik, T.; Gyarmati, G

Economic and Sustainability of Biodiesel Production-A Systematic Literature Review. Clean Technol. 2021,

3, 19-36. https://doi.org/

10.3390/cleantechnol3010002

Received: 15 December 2020

Accepted: 6 January 2021

Published: 8 January 2021

Publisher's Note: MDPI stays neutral with regard to jurisdictional clai$\mathrm{ms}$ in published maps and institutional affiliations.

Copyright: (C) 2021 by the authors. Licensee MDPI, Basel, Switzerland. This article is an open access article distributed under the terms and conditions of the Creative Commons Attribution (CC BY) license (https:// creativecommons.org/licenses/by/ $4.0 /)$.

\begin{abstract}
As Earth's fossil energy resources are limited, there is a growing need for renewable resources such as biodiesel. That is the reason why the social, economic and environmental impacts of biofuels became an important research topic in the last decade. Depleted stocks of crude oil and the significant level of environmental pollution encourage researchers and professionals to seek and find solutions. The study aims to analyze the economic and sustainability issues of biodiesel production by a systematic literature review. During this process, 53 relevant studies were analyzed out of 13,069 identified articles. Every study agrees that there are several concerns about the firstgeneration technology; however, further generations cannot be price-competitive at this moment due to the immature technology and high production costs. However, there are promising alternatives, such as wastewater-based microalgae with up to $70 \%$ oil content, fat, oils and grease (FOG), when production cost is below 799 USD/gallon, and municipal solid waste-volatile fatty acids technology, where the raw material is free. Proper management of the co-products (mainly glycerol) is essential, especially at the currently low petroleum prices $(0.29 \mathrm{USD} / \mathrm{L})$, which can only be handled by the biorefineries. Sustainability is sometimes translated as cost efficiency, but the complex interpretation is becoming more common. Common elements of sustainability are environmental and social, as well as economic, issues.
\end{abstract}

Keywords: biodiesel; sustainability; fuel blending; price competitiveness; cost effectiveness; microalgae

\section{Introduction}

Earth's fossil energy resources are limited; therefore, humanity must find out how to fully replace them from renewable sources. In the transportation sector, biofuels provide an opportunity. Besides their renewable nature, they are considered greenhouse gas (henceforth referred to as GHG)-neutral, as the previously absorbed carbon dioxide is released during their burning. However, the emission level of GHGs can be significant during their production stages from cultivation to processing [1]. Normally, the use of biodiesel results in higher nitrogen $\left(\mathrm{NO}_{\mathrm{x}}\right)$ and lower carbon monoxide and smoke emissions. This was confirmed by Nabi et al. by using nonedible neem oil and diesel-biodiesel blends [2] Kawano et al. [3] received the same results by using different blending rates of rapeseed oil methyl ester with petroleum. This may heavily affect their sustainability. We used sustainability in the generally accepted sense, and according to the so-called Brundtland report (p. 15): "Humanity has the ability to make development sustainable to ensure that it meets the needs of the present without compromising the ability of future generations to meet their own needs" [4]. In the case of biodiesel, sustainability should have three pillars: environmental, economic and social, and they should be analyzed together [5].

Biofuels can be either fuel additives or almost purely used. Their common characteristics are the organic raw material (e.g., cereals, oilseed crops, fat or waste with organic origin) and their renewable nature. Basically, there are two types of biofuels, ethanol for Otto engines and biodiesel for diesel engines. At this moment, the most common raw 
materials of biodiesel production are oil-rich plants, such as sunflower seed, rapeseed or palm trees.

The structure of the article is as follows. The second Section provides an overview of the major characteristics of the biodiesel sector including biodiesel generations, major raw materials, productions costs, the major producers and their blending rates. The third chapter demonstrates the research methodology, the technique with which the relevant articles were selected. Results are divided into two sub-sections: country-related analyses and global biodiesel issues. The final chapter summarizes the main results and provides conclusions.

\section{Major Characteristics of the Biodiesel Sector}

The basis of biodiesel production is the raw material. Based on the feedstocks and production methods, we can differentiate between three generations (Table 1).

Table 1. Biodiesel generations.

\begin{tabular}{cccc}
\hline Generations & Feedstocks & Conversion Process & Carbon Balance \\
\hline 1st & Rape, sunflower, palm, soybean, animal fat & Transesterification & Positive \\
\hline 2nd & Jatropha and nonedible oils & Transesterification & Positive \\
\hline 3rd & Algae and seaweeds & Algal synthesis & Negative \\
\hline
\end{tabular}

${ }^{*}$ It should be noted that the negative $\mathrm{CO}_{2}$ balance is based on the replaced $\mathrm{CO}_{2}$ in biodiesel production, which varies by the different algae species and technologies [6]. Source: authors' composition based on [7].

Regarding the production process, there are, basically, two methods: cold and hot press extraction with additional transesterification. The latter provides more oil, and therefore large production units use only that method. As a comparison, cold crushers can reach about $80 \%$ oil extraction, while hot press extraction (hexane crusher process) may reach up to $99 \%$ efficiency, resulting in almost no oil left in the meal [8].

Raw materials play the most important role in the biodiesel value chain. Therefore, their (highest possible) oil content has utmost importance. Depending on the raw material, this varies between $15 \%$ (soybean) and $70 \%$ (microalgae). Table 2 provides an overview of the currently used biodiesel raw materials and their oil content.

Table 2. Oil content of the major biodiesel feedstocks.

\begin{tabular}{ccc}
\hline Type of Oil & Feedstock & Oil Content (\%) \\
\hline Edible & Soybean & $15-20$ \\
\hline & Rapeseed & $37-50$ \\
\hline Nonedible & Palm & $20-60$ \\
\hline Other sources & Jatropha seed & $35-60$ \\
\hline Source: authors' composition based on [9]. & Microalgae & $30-70$ \\
\hline
\end{tabular}

In the case of, e.g., soybean oil, the raw material cost provided $75 \%$ of the total production cost based on data from the last 13 years (2007-2019) [10]. This is the reason why the use of used vegetable oils can be more profitable than that of any high-oleic, first-generation raw materials. Besides the raw material cost, low reactor efficiency and material/energy loss during the process could also be significant [11].

Due to the current high production costs, the sustainability of biodiesel production is questionable. Baudy et al. [12] analyzed 11 different biofuel feedstocks and claimed that none of them are economically sustainable even at a $50 \mathrm{USD} /$ barrel oil price as the end-users' cost is positive. From the end-users' perspective, biomass-based biodiesel has the lowest costs among the six biodiesel feedstocks. On the other hand, rapeseed biodiesel has the highest positive overall government budget impact, that is, $0.03 \mathrm{EUR} / \mathrm{L}$ in gaso- 
line equivalent at a $50 \mathrm{USD} /$ barrel oil price, while it goes up to $0.08 \mathrm{EUR} / \mathrm{L}$ in gasoline equivalent at a $180 \mathrm{USD} /$ barrel oil price. However, considering environmental and land use issues, microalgae are the least suitable source for biodiesel production with a high end-user cost even at a $180 \mathrm{USD} /$ barrel oil price $(0.18 \mathrm{EUR} / \mathrm{t}$ additional cost) and with negative overall government budget impact $(-0.08 \mathrm{EUR} / \mathrm{L}$ in gasoline equivalent at a 180 USD/barrel oil price) [12].

At the country level, Table 3 provides an overview of the biodiesel production costs of the major producers.

Table 3. Production cost of the major biodiesel producers, 2019.

\begin{tabular}{ccc}
\hline Countries & USD/L & Weighted USD/L * \\
\hline Argentina & 0.60 & 0.66 \\
\hline Brazil & 0.64 & 0.71 \\
\hline EU & 0.75 & 0.82 \\
\hline Indonesia & 0.68 & 0.75 \\
\hline USA & 0.42 & 0.47 \\
\hline * Weighting takes into account the approximately 10\% lower energy content of biodiesel compared to \\
petroleum [13]. Source: authors' composition based on [14,15].
\end{tabular}

The current, low oil price (West Texas Intermediate (WTI) crude oil is 45.52 USD/barrel [16]) results in a $0.29 \mathrm{USD} / \mathrm{L}$ petroleum price that causes unprofitable biodiesel production even for the most efficient producer, the USA. This is even worse if the lower energy content of biodiesel is taken into account (weighted USD/L price). Practically it means that without additional support, tax credit or blending mandate, biodiesel production could not be profitable even for the most efficient producers [1]. The major raw material is soybean in the USA, Argentina and Brazil. Although its oil content is low (only 18\%), the remaining meal is a valuable feed with good export markets for Argentina and Brazil [17]. In the case of the USA, the production process is also strengthened by genetic engineering to increase soybean yields and oil content. The Indonesian biodiesel production is based on palm oil with a production cost of $0.68 \mathrm{USD} / \mathrm{L}$, while the rapeseed-based European production is the most expensive among the analyzed countries $(0.75 \mathrm{USD} / \mathrm{L})$. However, it should be kept in mind that most of these values are subject to changes in exchange rates (local currency/USD), e.g., the strong euro against the US dollar in 2019 made the European production cost higher.

The world biodiesel production is highly concentrated, where the four largest producers provide $78.63 \%$ of the total production (Figure 1). The EU produced 14,600 million liters of biodiesel (31\% of the total production) and the USA produced 9031 million liters (19\% share), while the Indonesian and Brazilian productions were 7380 and 5800 million liters ( $16 \%$ and $13 \%$ of the global production, respectively).

Despite the highest production cost, the EU as a whole is the major biodiesel producer of the world. This reflects the highest share of diesel cars in Europe which was $41.9 \%$ of the vehicle fleet [18] with a 35.9\% share of new passenger cars in 2018 [19]. However, this differs greatly among the member states, e.g., this was 60.0\% in Spain, 51.9\% in France, $44.4 \%$ in Italy and $32.2 \%$ in Germany [18]. Biodiesel is used mostly for buses and light, medium and heavy commercial vehicles in the other significant producer countries, as well as being blended with petroleum according to the different blending mandates of the countries. Brazil can be characterized by a high share of flexible-fuel vehicles, while diesel passenger cars have a negligible role in the USA. 


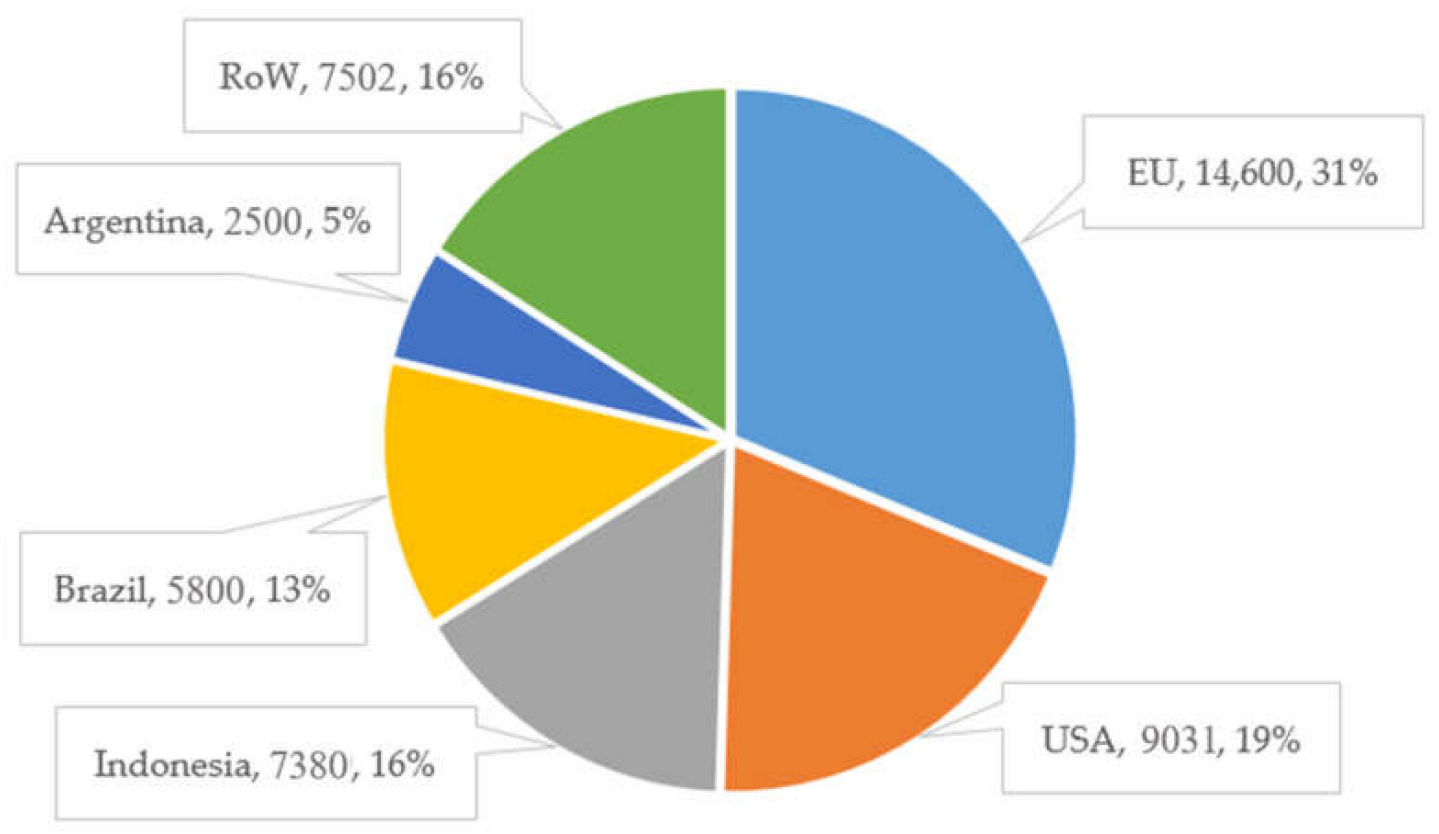

Figure 1. World biodiesel production and its composition, 2019 (million liters). Source: authors' composition based on [14].

As of the future, biodiesel production is expected to decrease by $2.53 \%$ in the next ten years; however, the market structure will not change significantly [14]:

- $\quad$ The TOP5 producer will be the same in 2029;

- The share of the EU, the USA and Indonesia will slightly decrease;

- Meanwhile, the share of Brazil and Argentina is expected to increase.

Beside the commercial vehicles, biodiesel is used as an additive to petroleum. Its share can vary between 1 (B1) to up to 100\% (B100). Blending mandates are an important and stable element of the biodiesel demand, and they also maintain and even boost the biodiesel production. Maintaining biorefineries is important, independent of the (low) oil prices, as they are an important source of innovations. Biodiesel blending mandates vary around the world [20]:

- Argentina introduced B10; however, the country exports more biodiesel than its domestic consumption;

- Brazil has the B10 mandate and the country is 100\% self-sufficient with almost no exports or imports;

- Biodiesel use in China and India is insignificant;

- The EU's blending objective for 2020 is B7; however, that may differ at the country level;

- Indonesia has recently introduced B20;

- No country-level mandates in the USA; only Oregon introduced B5 at the state level, while the B20 mandate is delayed for Minnesota.

\section{Materials and Methods}

To achieve a satisfactory pool of scientific results, five significant online databases were used: Scopus, Web of Science, JSTOR, ProQuest and Science Direct. This process was conducted in two steps. First, the largest database (Science Direct) was searched by using "biodiesel", "economic" and "sustainability" as keywords. We aimed to select articles that simultaneously deal with economic and sustainability issues and go beyond the simple production cost or sustainable production approach. Our initial screening resulted in more than 10,000 $(13,059)$ results. Therefore, the search was limited to English scientific articles published in the last 5 years (2015 or later) to implement the latest achievements in the review. This reduced the number of items to 1883 . Choosing energy 
and environmental sciences resulted in 1275 articles. Articles focusing mostly on the following issues were removed:

- Raw material production;

- Technology and production methods;

- Policy issues;

- GHG emissions savings;

- Non-fuel use (e.g., in power generation);

- Renewable energies and other biofuels within, e.g., jet fuel, ethanol, biobutanol, biogas, biomethane or biomass.

Second, this subsample was merged with the other four samples (Scopus, Web of Science, JSTOR, ProQuest). After sorting out the duplicates, we had 243 articles for in-depth analysis. Non-relevant articles were removed, resulting in 53 relevant studies. Figure 2 summarizes the steps of the literature selection.

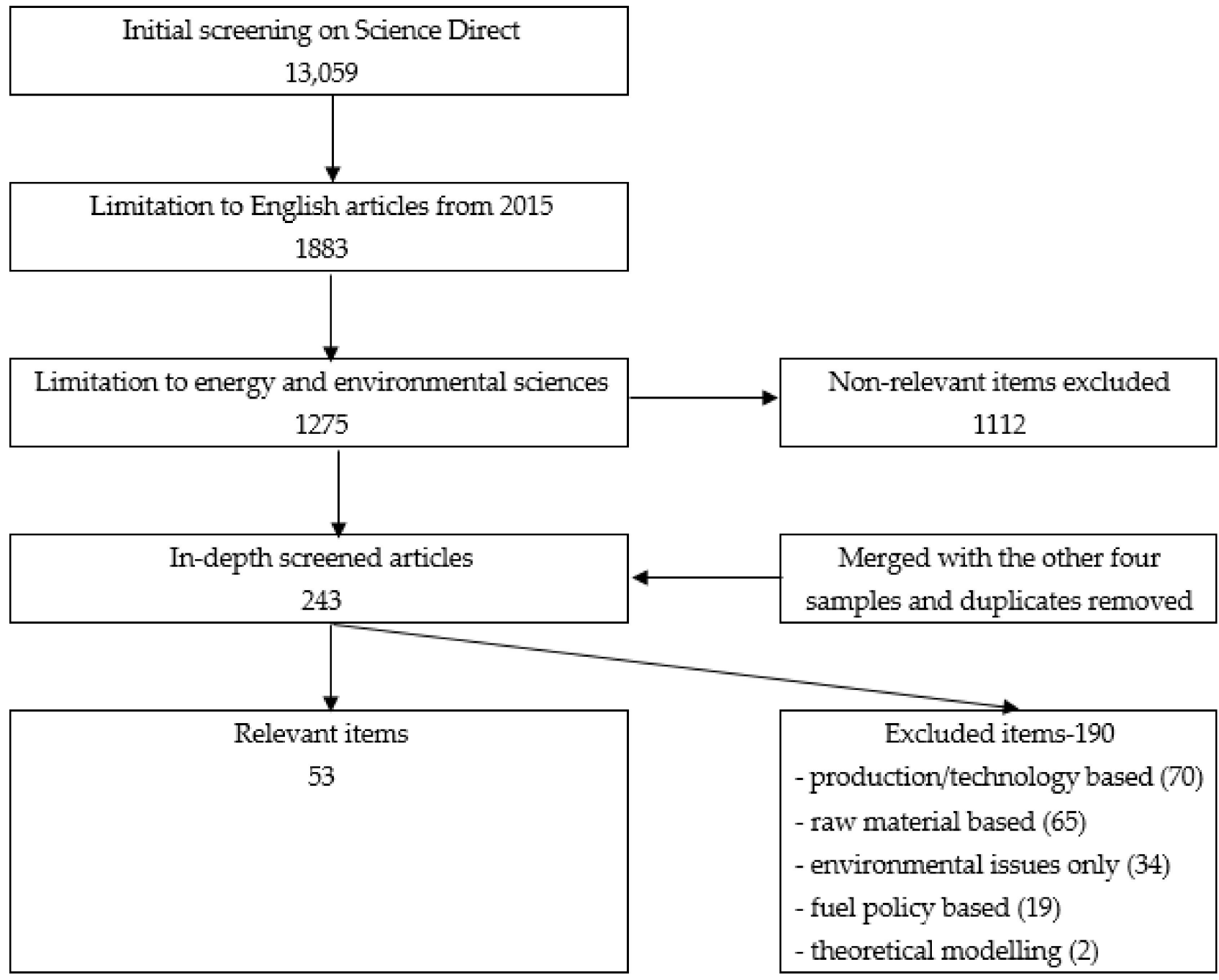

Figure 2. Milestones of the literature selection. 
The yearly distribution of the selected articles varied during the analyzed period; however, 2020, 2017 and 2016 were the most active years (Figure 3).

Regarding the journal distribution, Renewable \& Sustainable Energy Reviews is the primary source of the topic-related articles, where 21 out of 53 articles were published there (Figure 4). This is followed by the Journal of Cleaner Production (5 articles), while 3 articles were published in the Global Change Biology Bioenergy, the Chemical Engineering Research \& Design, Energy Conversion \& Management and Sustainability journals. The rest of the selected articles can be found in 13 different journals.

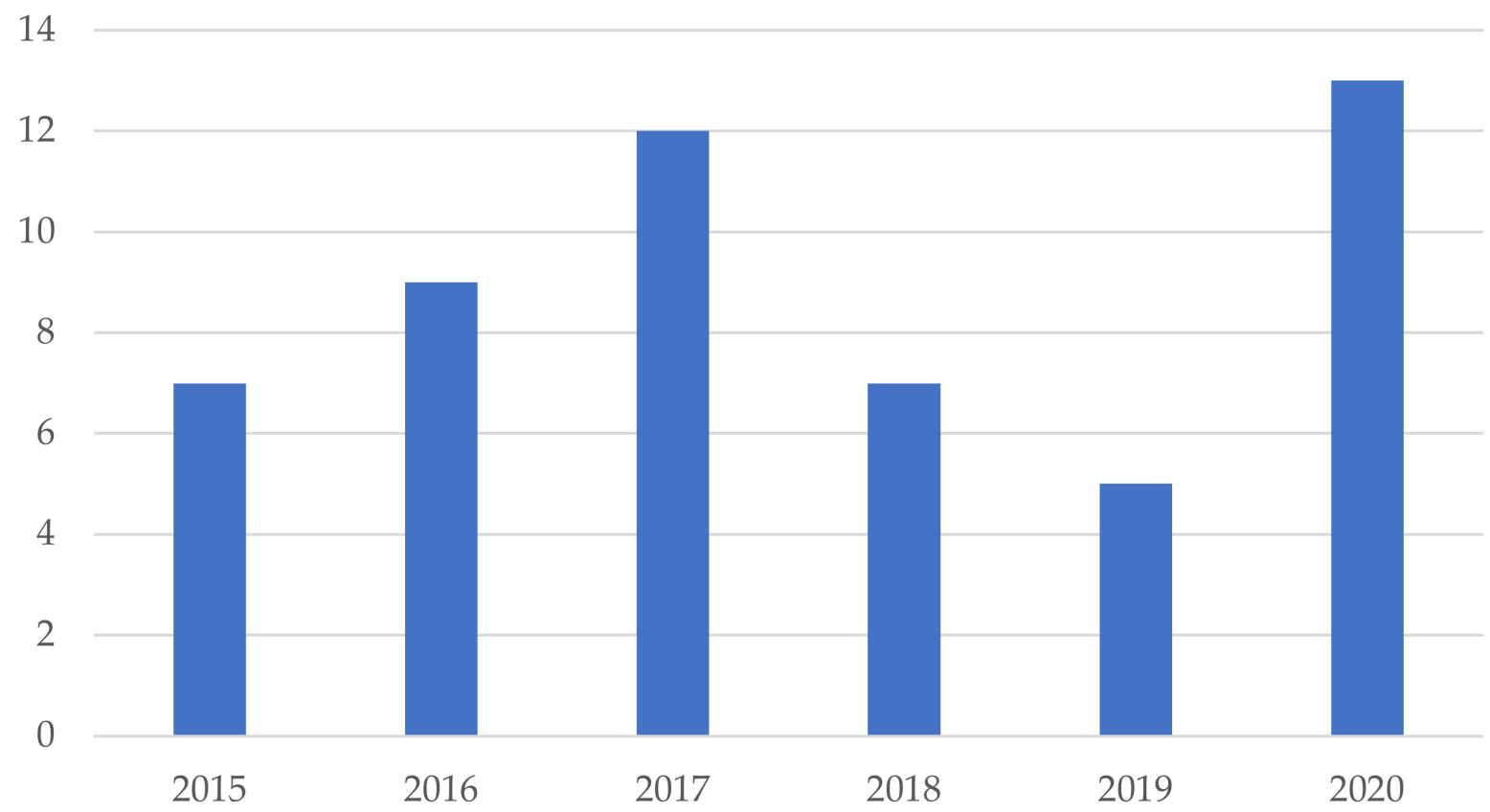

Figure 3. Yearly distribution of the selected articles.

Renewable \& Sustainable Energy Reviews

Journal of Cleaner Production

Energy Conversion \& Management

Sustainability

Chemical Engineering Research \& Design

Global Change Biology Bioenergy

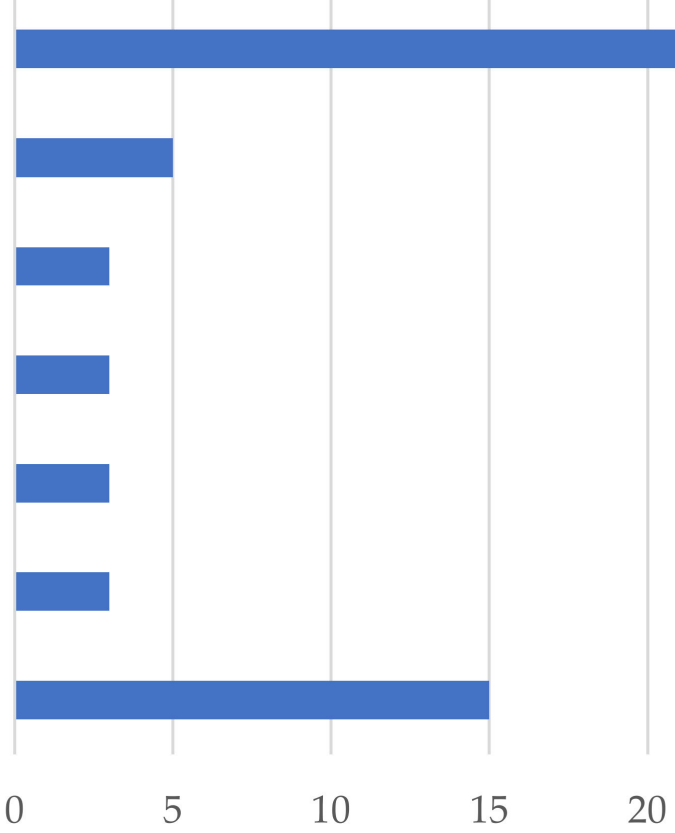

Figure 4. Journal distribution of the selected articles. 


\section{Results}

The selected articles can be grouped into two categories: approximately half of them analyze country-specific subjects, while the other half deal with generalized, world-level issues. Their common point is the joint analysis of the economic and sustainability sides of biodiesel production.

\subsection{Country-Related Analyses}

The profitability of the biodiesel production is hindered by the low oil prices, as well as high vegetable oil prices. These are the reasons for the widely used interventions, such as mandates, targets, subsidies and tax exemptions, as otherwise, production would not increase [21].

Due to its important role in global production, the Brazilian biodiesel industry is frequently studied in the related literature. According to De Oliveira et al. [22], biodiesel production in Brazil has increased significantly (from 736 to $3419,838 \mathrm{~m}^{3}$ in less than 10 years) and has already become one of the important sources of fuel. Biodiesel provides economic and environmental benefits, as the country can replace imported fossil diesel with locally produced biodiesel. Yet the biodiesel sector is struggling financially, and demand is unpredictable. Currently, soybean oil and beef tallow are the two main raw materials that must be expanded in the future. Rico and Sauer [23] pointed out that edible vegetable oil products are more expensive than biodiesel, and therefore farmers should be subsidized for providing raw material for biofuel production. Although local production substitutes import and results in savings, subsidies should also be considered. The situation was the same with ethanol production until that became price-competitive. They linked sustainability to production, although using biodiesel contributes to better air quality, as well as lower GHG emissions.

Miranda at al. [24] analyzed used vegetable oil as a source of biodiesel. According to their calculations, collecting oil only from the households of Sao Paolo can generate 693,600 L pure biodiesel (B100) every month. Revenues and savings come from an excess of pure biodiesel, glycerol, carbon credit and B20 use in the local bus fleet. These sum up to almost 1.3 million USD/month. The additional positive impact is the greener environment as better air quality was reported by many studies where biodiesel was used. From a logistical point of view, these refineries should be placed close to the populated areas where both supply and demand are granted. Transformation of used vegetable oil into biodiesel shows economic and environmental advantages too. Da Silva et al. [25] also tested waste cooking oil biodiesel in a generator and found that for up to a $30 \%$ blend, the energy production potential was equal to that of diesel, reducing greenhouse gas emissions by at least 33\%. The city of Sao Paulo has a production potential of waste frying oil of more than $8800 \mathrm{~m}^{3}$ per month, which is enough to meet the needs of its bus fleet, generating a monthly profit of USD 5,000,000 with savings of USD 5,000,000. In this way, the economic and technical viability of biodiesel production from residual frying oil exists. These were in line with Cesar and colleagues' results [26], where Brazilian waste oil biodiesel turned out to be both economically and technically sustainable. By lowering the waste load on the environment and using the oil to be disposed of, its effect on wastewater treatment is also positive. It should be also seen that all these positive externalities can be reached only if they are supported at the level of social government. Yang et al. [27] experienced the same for Japan where waste cooking oil-based biodiesel production proved to be environmentally, as well as economically, beneficial. They also highlighted lower emissions and waste recycling; however, using this product requires an effective collection system. Nevertheless, fluctuating world oil prices make gains from biodiesel use unstable. According to Cremonez et al. [17], Brazil has very good raw material resources, allowing for 
producing 372 million tons of biodiesel from soybeans and oilseeds for the transportation sector. They also highlighted that the production is below its capacity $(37 \%)$, which cannot be competitive.

Wastewater use also provides a promising alternative. Kligerman and Bouwer [28] found algae-based wastewater treatment beneficial from two aspects: this could provide a solution to the untreated wastewater, and it could be possible to produce biodiesel in an economically feasible way. According to the authors' calculations, this would generate at least a $10 \%$ profit margin by using only $40 \%$ of the municipal waste in Brazil; however, this depends on the biodiesel market price and the immature production technology. This also implies that operational costs may significantly fall shortly. The major advantage of this method is the free raw material.

Due to its population and increasing motorization, China has a continuously increasing demand for fuels, including biofuels. Different parts of China provide opportunities for different biodiesel raw materials. Xu et al. [29] pointed out, according to the endowments, that rapeseed, cottonseed, Jatropha and microalgae can also be an adequate option; moreover, used cooking oil is available in each Chinese region. The links sustainability to these renewable energies. Sun et al. [30] found microalgae biodiesel a promising option in China, albeit too expensive at this moment. They drew attention to the need for complex analysis where environmental sustainability and ecosystem services should be considered, as they can potentially be influenced by the biodiesel industry. Based on Chinese experiments, Chen et al. [31] identified variables of production costs: cultivation method, biomass productivity, purity of extracted lipid, plant size and size of capital investment (land, equipment and structures). For costs to be at an acceptable level, technologies need to be developed which would make low-cost equipment available to operate with efficient dewatering and extraction technologies. This could further promote sustainability. According to them, microalgae production is a good alternative for when oil fields are depleted and the production of other biodiesel feedstocks is difficult.

Dey et al. [32] summarized the Malaysian and Indonesian experiences. Palm oil biodiesel seemed to be environmentally beneficial, but not enough experience is available yet. As the palm oil production improves employment and livelihoods, as well as engine performance and emissions, this is an environmentally sustainable way of use. Population growth will increase the demand for food, as well as the demand for biodiesel because carbon emissions need to be reduced. Palm oil is a leading biofuel with a $35 \%$ production share, high estimated oil content (5000 kg oil/ha), high yield (4.2 Mt/ha) and low market price (660 USD/t). Van Noordwijk et al. [33] emphasized that the economically and ecologically sustainable (Indonesian) palm oil sector has an environmental optimum production level with maximized net emission savings that depends mainly on the proper amount of $\mathrm{N}$ fertilizer use. However, Yusoff et al. [34] questioned the sustainability of palm oil production due to the deforestation of tropical forests. They also noted that Malaysia solved this problem by preserving forests, limiting palm oil plantation and using other agricultural crop areas for plantations. Although Malaysia is rich in palm oil, biodiesel adoption is low due to several reasons such as insufficient governmental incentives to motivate transportation companies, price-determined transportation services and lack of competitive pressure [35]. Zailani et al. [35] proposed different governmental actions (subsidies and/or tax exemptions) for solving these problems as biodiesel use can lead to several advantages (e.g., lower dependency on fossil fuel and better air quality).

Faurani et al. [36] argued that biodiesel production in Indonesia affects national production, economic growth, labor demand, unemployment and poverty. However, its effectiveness and impact depend on many factors such as export price, dollar-rupee exchange rate, calorific value and quality of the product/raw material and the situation of the world economy. According to their simulation, urban poverty decreased by $2.71 \%$, due to the increasing economic growth $(+3.65 \%)$ and industrial production $(+4.41 \%)$. This can increase the labor demand by $0.79 \%$, while reducing unemployment by $24.39 \%$. 
Harsono et al. [37] found the mix of waste fish with plant residues as a promising alternative for Indonesia. By using B100, they experienced higher fuel consumption compared to the commercially sold diesel fuel $(0.69 \mathrm{~L} / 10 \mathrm{~km}$ versus $0.65 \mathrm{~L} / 10 \mathrm{~km})$; however, this was lower consumption than that of the low-sulfur pure diesel fuel $(1.03 \mathrm{~L} / 10 \mathrm{~km})$. This could make it possible to achieve economically sustainable fuel production, and fish can be used to produce zero waste.

Ianda et al. [38] used a multi-country approach on biodiesel production and consumption for sub-Saharan African countries, namely, Botswana, Malawi, Mozambique, Namibia, South Africa, Tanzania, Zambia and Zimbabwe. This helps to find the best raw material and to cooperate in production and use of biodiesel, as well as the energy generated from the by-products. They found that palm oil production is the cheapest but Jatropha oil production can generate five times more jobs. Due to the high production cost, biodiesel production requires significant support (subsidies and/or tax reduction). Besides the renewable notion of biodiesel, sustainability included social inclusion and the development of less-favored regions. Kgathi et al. [39] also analyzed Jatropha biofuel in Botswana and economic impacts were not convincing due to the low yields (no previous breeding), and wastelands and degraded agricultural lands were not suitable for production as yields were even lower than expected. They evaluated eight sustainability indicators related to Jatropha biofuel (impacts can be positive or negative): macro-economic impacts $(+)$, economic viability (mainly - ), access to land ( - on large scale and + on small scale), food security $(-)$, biodiversity $(-)$, water resources $(-)$, energy balance $(+)$ and climate change $(+)$.

Baral et al. [40] calculated the environmental and economic sustainability of Jatropha biodiesel in Nepal. This depended largely on the crop quality of the plant and the chemical parameters of the oil. A seed yield of $>3.9 \mathrm{t} / \mathrm{ha}$ and a high oil content of the Jatropha variety (oil yield of $>50 \mathrm{wt} \%$ ) result in a similar retail price to that of the local conventional diesel price (1 USD/L). Reducing the $\mathrm{CO}_{2}$ emissions of Jatropha biodiesel below the conventional diesel parameter $\left(87.23 \mathrm{~g} \mathrm{CO}_{2} \mathrm{e} / \mathrm{MJ}\right)$ is not easy. This requires high seed (over $5 \mathrm{t} / \mathrm{ha}$ ), as well as oil, yield (over $50 \%$ by weight). Moreover, only marginal areas should be used because further afforestation is needed. However, Jatropha can be grown elsewhere. Corral et al. [41] investigated the operation of a Jatropha production wastewater treatment plant on the Spanish island of Fuenteventura. Depending on the size of the area and the distances, the needs of the island's motor traffic can be met with a Jatropha plant. This means both economic and environmental sustainability. The transport diesel oil need of the island is 40,960 tons. Within a $10 \mathrm{~km}$ radius of wastewater treatment plants, production would be 1249 tons which is $27.56 \%$ of the total requirements of the island. Castro Gonzales [42] underlined the need for favorable soil, climatic and management conditions to make Jatropha biodiesel production both economically and environmentally feasible.

Habibullah et al. [43] showed that the production of pure biodiesel in Bangladesh is expensive. Its expected cost is between 1.6 and $23.96 \mathrm{USD} / \mathrm{L}$, while regular diesel costs only $0.71-0.91 \mathrm{USD} / \mathrm{L}$, and $20 \%$ mustard biodiesel blend is $0.77 \mathrm{USD} / \mathrm{L}$. Production cost can be lowered by reducing the raw material cost and the processing cost and by recycling the methanol after transesterification if it is produced commercially.

Basili et al. [44] studied the economic and environmental sustainability of blending Brassica carinata, an inedible flowering plant as a second-generation biofuel, with wheat (and eventually other plants) in Italy. Based on their examination of five Tuscan plants, it was found that the yields and results reported in the literature can only be achieved under optimal conditions, and public support is needed for economic viability. In Indonesia, the price of palm oil was 655 USD/metric $t$ or 486 EUR/t in February 2018. Overall, the crude oil price was 525-598 EUR/t. In Italy, the cost of Brassica carinata oil was $618 \mathrm{EUR} / \mathrm{t}$, which is higher than that of the Indonesian cost. 
Durisic et al. [45] examined the economic viability of the Serbian biodiesel sector. Serbia can produce 128,000-266,000 tons of biodiesel from oilseed crops, 10,000 tons from collecting waste cooking oil and $8000 \mathrm{t}$ from tomato, grape and tobacco seeds. However, this requires tax exemption and other governmental supports. Using edible vegetable oils as a potential feedstock for biodiesel cannot be considered a long-term solution. Therefore, it is important to explore inedible raw materials and waste cooking oil seems to be the most promising. This presupposes that collection is strictly regulated centrally, both on the side of service providers and households.

Ganev et al. [46] examined Bulgarian examples by using an environmental criterion, and the average price of biodiesel (B100) in the period considered (2016-2020) was $428 \mathrm{USD} / \mathrm{t}$. This was $14 \%$ higher than the average biodiesel price under the economic criterion (378 USD/t). On the other hand, total greenhouse gas emissions were $6.6 \%$ lower when the environmental criterion was used.

Renewable energy strategies should be carefully planned as they themselves may be neither sustainable nor climate-friendly [21]. Therefore, Parsons at el. [47] drew attention to sustainable production. Even if it is hard to replace certain raw materials such as palm oil due to its unique fatty acid profile and low price, it is important to slow down or stop further tropical deforestation. Sometimes, it is hard to take into account the social aspects of sustainability. Sajid and Lynch [48] proposed the GreenZee model in Canada that translates social impacts to monetary terms through using harmonized currency units. Nguyen et al. [49] used the Inclusive Impact Index (Triple I) for evaluating different biodiesel blends with a three-dimensional sustainability index. This incorporated economic, environmental, human well-being and social issues. Based on this method, the B20 blend was the best short-term option for cruise ship engines in Vietnam.

Another important issue is the rebound effect. For instance, Hochman et al. [50] found by their modeling work that the introduction of biofuels increases the amount of total fuel consumed and reduces the average fuel price in South Korea. Therefore, there is an environmentally damaging recovery in which gasoline consumption is reduced by less than the quantity of surplus biofuels. For example, with a $25 \%$ increase in biofuel supply as an ambitious scenario under the given elasticity of demand, total petroleum consumption will decrease by only $8.7 \%$ on average, with a rebound effect of $65.2 \% . \mathrm{CO}_{2}$ emissions will be reduced by 0.27 million tons, which means less burden on the environment and increased economic prosperity. The authors considered forestry residues as a promising future alternative, especially because the South Korean biodiesel production is based on imported feedstocks.

\subsection{Global Biodiesel Issues}

As a matter of sustainability, we should deal with its many different aspects. Related indicators should cover the direct and indirect effects of biodiesel production. According to Živković et al. [51], there are three different aspects of sustainability. Economic sustainability basically means economic competitiveness with the cost of other energy sources. Social sustainability implies equitable access to different issues, such as ecological resources, food or health safety. Finally, environmental sustainability includes, e.g., soil and water quality, GHGs and biodiversity. These indicators are important to measure not only advantages but also disadvantages of biodiesel production. As production cost is the major burden of its further expansion, future actions are driven by cost effectiveness by using cheaper and preferably nonedible raw materials and energy- and waste-saving technologies. The primary driving force on this path should be governmental policy. Thomassen et al. [52] proposed the Environmental Techno-Economic Assessment (ETEA) to harmonize the different results of the sustainability assessments. They identified four challenges: lack of a clear framework, the proper adaptation of the methodology, lack of harmonized assumptions and the integration of the technological process. Based on this methodology, algae-based biorefineries seem to be a promising option; however, their social impacts should also be integrated into a full sustainability assessment. Efroymson et al. [53] 
highlighted that proper choice of economic and environmental measurement methods is also important because we get different results by calculating the internal rate of return (IRR), or even the net present value (NPV), and some factors such as social and economic indicators may correlate. Manufacturing features, downtime and high maintenance also impact the costs and $\mathrm{CO}_{2}$ emissions of the algal biofuels, and thus their sustainability.

Marketing and use of co-products are as important as the biodiesel production itself. Zhu [54] highlighted that only high-value products can make the operation of biorefineries economic in the future. He also identified two important limitations: the energy balance of the process should be positive and cost-effective. In his analysis, he restricted sustainability to the sufficient demand for high-value products. These algae-based products can be grouped into three categories: biofuels, co-products and food/feed. The biofuels category contains biodiesel, bioethanol, biohydrogen, biogas and other types; co-products are fine chemicals, cosmetics and medicine; and food/feed can be protein, nutrition and animal feed [54].

This is the reason why sustainability also should cover not only the primary product (in our case biodiesel) but also glycerol, the main co-product. Severo et al. [55] suggested that using sustainable metrics is also important, such as the water footprint or global warming potential. Only environmental benefits are not enough to attract private investors to finance a biorefinery under the current, low revenues compared to the petroleum refineries.

Taking into consideration the increasing water scarcity, the water footprint is becoming a more and more important issue in biodiesel production too. Table 4 provides an overview of the water need of the different uses of rapeseed-based biodiesel. However, these values highly depend on the rapeseed varieties, soil quality, use of proper production methods and the quality and quantity of the different inputs.

Table 4. Water use (L/passenger $/ \mathrm{km})$ of the differently used biodiesel fuels.

\begin{tabular}{ccc}
\hline Transport Mode & Crop Source & Water Footprint \\
\hline Airplane & Rapeseed & $142-403$ \\
\hline Car (large) & Rapeseed & $214-291$ \\
\hline Car (small, efficient) & Rapeseed & $65-89$ \\
\hline Bus & Rapeseed & $67-126$ \\
\hline Train & Rapeseed & $15-40$ \\
\hline
\end{tabular}

* Results are based on first-generation biofuels. Source: authors' composition based on [9].

Based on the results of Jacob et al. [56], only wastewater-based algae biofuels production could be economically feasible. According to them, the sustainability of the microalgae biodiesel has three important aspects to be addressed: energy and carbon balance, the environmental effects and production costs. Juneja and Murthy [57] found that this type of biodiesel production is more expensive than petroleum but provides negative GHG emissions. They translated sustainability to positive energy balance (energy produced is greater than the energy used for production). Kumar and Singh [58] pointed out that algal biodiesel production alone is not rational and different co-products (algal meal, algal oil, electricity, digestate and heat) are important to make the process economic and sustainable. Despite the recent improvements in this field, algal biodiesel production is still not profitable, and the energy balance of the process is unsustainable. Based on the modeling research conducted by Pinedo et al. [59], the microalgae-based biodiesel production cost is $2.49 \mathrm{USD} / \mathrm{kg}$ which already includes the revenues from co-products (glycerol and fertilizer) and incentives to promote renewable fuels. At this moment, this cannot be competitive with petroleum or even the first-generation biodiesel prices. They also drew attention to the need for integrated biorefineries because economically advanced biodiesel production requires valuable co-products. In their research, sustainability was represented by a risk analysis identifying the major safety events (fire, explosion and toxic release). 
Lee and Dan [60] found that the microalgae biodiesel system has a low value factor but high $\mathrm{CO}_{2}$ mitigation potential. The value factor is the ratio of the life cycle energy efficiency and the life cycle production cost increment. Future technical improvements are expected to lower the energy need of production; thus, they make this type of biodiesel production price competitive. According to their research, the most commonly used sustainability indicators are performance, economic, social, environment and resource. Bravo-Fritz et al. [61] studied the economic and environmental sustainability of algae. The selection of cultured species (better biomass productivity and increased lipid accumulation) had a significant effect on their net present value. During the research, they were able to reach the production price of conventional gasoline and even go below that. Depending on the composition of biodiesels, the selling price must be between 1 and 3.5 USD/L for profitability. Doshi et al. [62] also found positive environmental, social and economic impacts of the different types of biofuels they studied. Although microalgae provide a solution to many shortcomings of first-generation biofuels, their high production and energy costs are significant barriers. Nevertheless, they consider microalgae the fuel of the future.

Habib et al. [63] also highlighted that the largest cost items in the supply chain are the installation and raw materials. This requires more efficient technology. They recommended the use of higher waste oil (WAF-SCND model) that would also make it possible to increase environmental and social impacts. Another promising biodiesel feedstock is the so-called fat, oils and grease (FOG). They found that by paying an extra $1.13 \%$ for biodiesel, a desirable social and environment protection level can be achieved. It was also found that a $5 \%$ increase in the economic target, a $6 \%$ increase in the environmental target and a $7 \%$ decrease in the social target completely ruled out the risk of epistemic uncertainty. Abomohra et al. [64] found them more competitive than other lipid-rich sources. This means that taking into account the world market price of crude oil, the cost of FOG should not exceed $799 \mathrm{USD} /$ gallon. According to their data, the estimated price of yellow and brown fats was only around USD $412 / \mathrm{t}$ and $224 \mathrm{USD} / \mathrm{t}$, respectively, so they are competitive products. From an environmental point of view, rapeseed biodiesel is energy-intensive and contributes significantly to global warming. Soybeans are not a good choice either, despite their low energy consumption and low emissions. Yellow fat proved to be the best option from this aspect. Gaeta-Bernardi et al. [65] suggested the municipal solid waste-volatile fatty acids (MSW-VFA) technology, which proved to be more efficient and competitive than even the waste oil. The present biodiesel prices cannot be competitive; however, they also depend on other factors, such as state support, continuous and reliable supply of raw materials and the use of glycerin as a cost-reducing co-product. They calculated that a $1.48 \mathrm{USD} / \mathrm{L}$ selling price can make a $0.08-0.1 \mathrm{USD} / \mathrm{L}$ profit. Regardless of the technology, Gebremariam et al. [66] found that the highest-cost item is the raw material. Therefore, it is necessary to find lower-cost raw materials. Inexpensive materials include eggshells, scallop shells, crustaceans, coconut shell bio-carbon, kraft lignin and pyrolyzed sugar. Moreover, these are recyclable. Technological improvements will reduce production costs.

On the basis of a literature study, Chamkalini et al. [67] showed that biodiesel does not always compete with crude oil in terms of production efficiency. The environmental effects are not clear either, as some research has been conducted under laboratory conditions, which may distort the results. Their impact analysis focused mainly on energy demand and greenhouse gas emissions. With the depletion of hydrocarbon storage, the sensitivity of society's environmental problems and hopefully the development of new technologies, the algae biodiesel industry may be more attractive than that of fossil fuels. This price disadvantage was strengthened by Chowdury et al. [68]. They stated that algae are not yet economically viable as a source of biofuels at present, despite the fact that some species can produce up to 70\% lipids from their dry weight. Dutta et al. [69] justified that better-quality oils with higher calorific value are more economically viable. This depends on the geographical area, seasonal variations in cultivation, labor costs, solvents used and other factors. They calculated that the minimum selling price of biodiesel was USD 10.55/GGE (gasoline gallon equivalent in 2011 dollars). The development of production and 
management processes can improve economic viability and efficiency to make microalgaebased systems economically and environmentally sustainable. Callegari et al. [9] confirmed an ever-increasing industrial and scientific research that significantly increases the market share of biofuels due to their lower environmental load. They found that energy produced, as well as emissions of biodiesel, are lower than those of fossil diesel (32.8 MJ/L versus $35.7 \mathrm{MJ} / \mathrm{L}$, and $2.48 \mathrm{~kg} \mathrm{CO}_{2} / \mathrm{L}$ versus $2.638 \mathrm{~kg} \mathrm{CO}_{2} / \mathrm{L}$ ). Nevertheless, similarly to the fossil resources, raw materials are not available indefinitely, so the potential stocks are finite as well. Nevertheless, they will be the dominant fuels of the future.

Granjo et al. [70] drew attention to the need for a more integrated and broader supply chain and product portfolio which can generate a variety of integration opportunities. They found that production costs can be reduced from 795 to 584 USD/t by using new raw materials (soy meal, lecithins and soy deodorization distillate (SODD) products). They can be used to reduce energy and water consumption for economic and environmental sustainability.

\section{Summary and Conclusions}

Fossil energy resources are finite; therefore, there is a continuously growing need for renewable alternatives. Biodiesel is one of the options. The EU is a major producer, which is in line with its high share of diesel vehicles. The currently used raw materials among the major producers are rapeseed and sunflower seed (EU), soybeans (Argentina, Brazil, USA) and palm oil and Jatropha oil (Indonesia). The USA can produce biodiesel at the cheapest price $(0.42 \mathrm{USD} / \mathrm{L})$, but even that price is much higher than that of petroleum (0.29 USD/L).

Country-related biodiesel studies dealt with the major producers, as well as major raw materials. Raw materials vary from country to country; however, mostly high-oleic plants are used. Future alternatives are also different, but mostly different wastes and residues were mentioned. Besides the economic issues (lower dependency, lower costs, development of less-favored regions), different aspects of sustainability also appeared, such as lower GHG emissions or deforestation. Joint analysis of the economic and sustainability sides of biodiesel production is becoming increasingly important. Table 5 summarizes the major characteristics of the country-related studies.

Table 5. Summary of the country-related analyses.

\begin{tabular}{|c|c|c|c|}
\hline Country & Current Raw Materials & Promising Alternatives & Major Issues \\
\hline Brazil & soybean and beef tallow & $\begin{array}{l}\text { used cooking oil, algae-based } \\
\text { wastewater treatment }\end{array}$ & $\begin{array}{c}\text { lower dependency, waste } \\
\text { management, better air quality, } \\
\text { lower GHG emissions }\end{array}$ \\
\hline China & rapeseed, cottonseed, jatropha oil & microalgae, used cooking oil & lower costs, sustainability \\
\hline Indonesia (Malaysia) & palm oil & $\begin{array}{l}\text { waste fish with plant residues, } \\
\text { Brassica carinata }\end{array}$ & $\begin{array}{c}\text { lower carbon } \\
\text { emissions, deforestation }\end{array}$ \\
\hline Sub-Saharan Africa & palm oil, jatropha oil & - & $\begin{array}{c}\text { renewable, development of } \\
\text { less-favored regions }\end{array}$ \\
\hline Nepal & jatropha oil & - & lower $\mathrm{CO}_{2}$ emissions \\
\hline South Korea & imported feedstocks & forestry residues & $\begin{array}{l}\text { lower } \mathrm{CO}_{2} \text { emissions, } \\
\text { rebound effect }\end{array}$ \\
\hline
\end{tabular}

Source: authors' composition.

Although economic issues play a decisive role in investment decisions, scientific research is not limited by them. Besides the commonly used raw materials, science seeks to find more sustainable solutions and try to make them financially viable. As the major cost item of biodiesel production is the raw material, finding free or cheap resources is essential. Used vegetable oil is available in large amounts but the proper collection should be organized. Besides biodiesel production, microalgae-based wastewater treatment could 
provide a solution to the untreated wastewater. FOG-based (fat, oils and grease) and municipal solid waste-volatile fatty acids technologies also provide many advantages.

Under the current circumstances, economic sustainability itself is simply unsustainable. Biodiesel production is closely linked to other areas of life such as employment, food, economy, feedstock production, chemistry, technology, innovation and environmental protection. This requires a complex, multi-dimensional approach. The related literature suggests many options, such as the GreenZee model that translates social impacts to monetary terms through using harmonized currency units, or the Inclusive Impact Index (Triple I) for evaluating different biodiesel blends with a three-dimensional sustainability index. However, potential side effects, such as the rebound effect, should also be carefully implemented into the system.

Global biodiesel issues deal with the three major aspects of the sustainability: economic, environmental and social. Economic sustainability concentrates on lower production cost and higher profit. This suggests new, preferably nonedible raw materials, as well as the use of energy- and waste-saving technologies. The central element of environmental sustainability is the lower environmental load. The major elements related to social sustainability were employment and the use of local resources in favor of the local community. Measuring tools are various, starting from the energy balance to the Environmental Techno-Economic Assessment. According to the studies analyzed, potential and promising biodiesel alternatives are microalgae; fat, oils and grease; different solid wastes; and other nonedible raw materials. Table 6 summarizes the major elements of the global biodiesel studies.

Table 6. Summary of the global biodiesel studies.

\begin{tabular}{|c|c|c|c|c|}
\hline Topic & \multicolumn{4}{|c|}{ Major Elements } \\
\hline Economic sustainability & $\begin{array}{l}\text { preferably nonedible } \\
\text { raw materials }\end{array}$ & $\begin{array}{l}\text { Energy-and } \\
\text { waste-saving } \\
\text { technologies }\end{array}$ & cost effectiveness & $\begin{array}{c}\text { marketing and use of } \\
\text { co-products (integrated } \\
\text { biorefineries) }\end{array}$ \\
\hline $\begin{array}{l}\text { Environmental } \\
\text { sustainability }\end{array}$ & $\begin{array}{l}\text { low or negative GHG } \\
\text { emissions, especially algae }\end{array}$ & $\begin{array}{l}\mathrm{CO}_{2} \text { mitigation, } \\
\text { global warming }\end{array}$ & lower water footprint & $\begin{array}{l}\text { waste management, } \\
\text { recycling }\end{array}$ \\
\hline Social sustainability & employment & $\begin{array}{l}\text { use of local raw } \\
\text { materials for the } \\
\text { local society }\end{array}$ & & \\
\hline Methodological tools & energy balance & $\begin{array}{l}\text { internal rate of return, } \\
\text { net present value }\end{array}$ & risk analysis & $\begin{array}{c}\text { Environmental } \\
\text { Techno-Economic } \\
\text { Assessment }\end{array}$ \\
\hline $\begin{array}{l}\text { Potential and } \\
\text { promising alternatives }\end{array}$ & microalgae & fat, oils and grease & $\begin{array}{l}\text { municipal solid } \\
\text { waste-volatile } \\
\text { fatty acids }\end{array}$ & $\begin{array}{c}\text { eggshells, scallop shells, } \\
\text { crustaceans, coconut } \\
\text { shell bio-carbon, kraft } \\
\text { lignin and } \\
\text { pyrolyzed sugar }\end{array}$ \\
\hline
\end{tabular}

Source: authors' composition.

There are clear common points in the related articles. It could be concluded that:

- Food versus feed is an important issue of the first-generation production, especially in some African and Asian countries, and edible raw materials cannot provide a longterm solution;

- The majority of the current biodiesel production is not competitive with the low petroleum prices; however, state support can make biodiesel production economically viable, for example, through tax exemptions and subsidies;

- Wastewater-based microalgae production could be economically feasible due to the free raw material, followed by used vegetable oil; 
- Co-products are as important as the major product; therefore, only biorefineries can be successful. Due to the size and weight of the currently used raw materials, distances and logistics must be taken into account during their location planning process;

- $\quad$ Besides production cost, other aspects should be included into any analyses, such as GHG emissions, e.g., via negative $\mathrm{CO}_{2}$ balance of algal production;

- A wider interpretation of sustainability is better and that should go far beyond the simple economic issues. In other words, sustainability should have other pillars than economic.

Different future research directions may also be identified. First, other aspects of this topic could be analyzed, such as environmental, social or policy aspects of the biodiesel industry. Second, the time horizon could be expanded to compare our major results with previous findings and draw new conclusions. Third, all the excluded topics could be analyzed, e.g., sustainability of the raw material production, different aspects of the GHG emissions related to biofuels, and other biofuels, as well as renewable energies in general.

Author Contributions: Conceptualization, T.M.; methodology, T.M. and G.G.; formal analysis, T.M. and G.G.; resources, T.M.; data curation, T.M.; writing-original draft preparation, T.M. and G.G.; writing-review and editing, T.M. and G.G. All authors have read and agreed to the published version of the manuscript.

Funding: This research received no external funding.

Institutional Review Board Statement: Not applicable.

Informed Consent Statement: Not applicable.

Data Availability Statement: Publicly available datasets were analyzed in this study. These data can be found here: https://www.card.iastate.edu/research/biorenewables/tools/hist_bio_gm.aspx; https://stats.oecd.org/\#; https://www.irs.gov/individuals/international-taxpayers/yearly-averagecurrency-exchange-rates.

Acknowledgments: The authors wish to thank the Editor-in-Chief, Patricia Luis for the invitation to contribute to the Special Issue entitled "Feature Papers 2020".

Conflicts of Interest: The authors declare no conflict of interest.

\section{References}

1. Mizik, T. Impacts of International Commodity Trade on Conventional Biofuels Production. Sustainability 2020, 12, 2626. [CrossRef]

2. Nabi, M.N.; Akhter, M.S.; Shahadat, M.M.Z. Improvement of engine emissions with conventional diesel fuel and diesel-biodiesel blends. Bioresour. Technol. 2006, 97, 372-378. [CrossRef] [PubMed]

3. Kawano, D.; Ishii, H.; Goto, Y. Effect of Biodiesel Blending on Emission Characteristics of Modern Diesel Engine; No. 2008-01-2384. SAE Technical Paper; SAE International: Warrendale, PA, USA, 2008. [CrossRef]

4. Commission, B. Our Common Future; Oxford University Press: Oxford, UK, 1987; p. 383.

5. Esteves, V.P.P.; Morgado, C.d.R.V.; Araujo, O.D.Q.F. Regional and temporal sustainability assessment of agricultural-based biodiesel. Clean Technol. Environ. Policy 2020, 22, 956-978. [CrossRef]

6. Bai, A.; Popp, J.; Petô, K.; Szőke, I.; Harangi-Rákos, M.; Gabnai, Z. The significance of forests and algae in $\mathrm{CO}_{2}$ balance: A Hungarian case study. Sustainability 2017, 9, 857. [CrossRef]

7. Naik, S.; Goud, V.V.; Rout, P.K.; Jacobson, K.; Dalai, A.K. Characterization of Canadian biomass for alternative renewable biofuel. Renew. Energy 2010, 35, 1624-1631. [CrossRef]

8. Jaeger, W.K.; Siegel, R. Economics of Oilseed Crops and Their Biodiesel Potential in Oregon's Willamette Valley; Special Report 1081; Oregon State University, Extension Service: Corvallis, OR, USA, 2008.

9. Callegari, A.; Bolognesi, S.; Cecconet, D.; Capodaglio, A.G. Production technologies, current role, and future prospects of biofuels feedstocks: A state-of-the-art review. Crit. Rev. Environ. Sci. Technol. 2020, 50, 384-436. [CrossRef]

10. CARD. Historical Biodiesel Operating Margins. Iowa State University, Center for Agricultural and Rural Development. Available online: https:/ / www.card.iastate.edu/research/biorenewables/tools/hist_bio_gm.aspx (accessed on 20 February 2020).

11. Amiri, P.; Arabian, D. The Effect of Reactor Configuration and Performance on Biodiesel Production from Vegetable Oil. J. Appl. Biotechnol. Rep. 2016, 3, 403-411.

12. Baudry, G.; Delrue, F.; Legrand, J.; Pruvost, J.; Vallée, T. The challenge of measuring biofuel sustainability: A stakeholder-driven approach applied to the French case. Renew. Sustain. Energy Rev. 2017, 69, 933-947. [CrossRef] 
13. European Commission. Directive (EU) 2015/1513 of the European Parliament and of the council of 9 September 2015 amending Directive 98/70/EC relating to the quality of petrol and diesel fuels and amending Directive 2009/28/EC on the promotion of the use of energy from renewable sources. Off. J. Eur. Union 2015, 239, 1-29.

14. OECD/FAO. OECD-FAO Agricultural Outlook 2020-2029. Available online: https://stats.oecd.org/\# (accessed on 9 December 2020).

15. IRS. Yearly Average Currency Exchange Rates. Available online: https://www.irs.gov/individuals/international-taxpayers/ yearly-average-currency-exchange-rates (accessed on 9 December 2020).

16. Bloomberg. Markets Energy. Available online: https://www.bloomberg.com/energy (accessed on 9 December 2020).

17. Cremonez, P.A.; Feroldi, M.; Nadaleti, W.C.; de Rossi, E.; Feiden, A.; de Camargo, M.P.; Cremonez, F.E.; Klajn, F.F. Biodiesel production in Brazil: Current scenario and perspectives. Renew. Sust. Energy Rev. 2015, 42, 415-428. [CrossRef]

18. ACEA. Passenger Car Fleet by Fuel Type. Available online: https://www.acea.be/statistics/tag/category/passenger-car-fleetby-fuel-type (accessed on 10 December 2020).

19. ACEA. Fuel Types of New Passenger Cars. Available online: https://www.acea.be/statistics/tag/category/share-of-diesel-innew-passenger-cars (accessed on 10 December 2020).

20. Lane, J. Biofuels Mandates Around the World: 2019. BiofuelsDigest. Available online: https://www.biofuelsdigest.com/bdigest/ 2019/01/01/biofuels-mandates-around-the-world-2019/ (accessed on 20 January 2020).

21. Naylor, R.L.; Higgins, M.M. The political economy of biodiesel in an era of low oil prices. Renew. Sust. Energy Rev. 2017, 77, 695-705. [CrossRef]

22. De Oliveira, F.C.; Coelho, S.T. History, evolution, and environmental impact of biodiesel in Brazil: A review. Renew. Sust. Energy Rev. 2017, 75, 168-179. [CrossRef]

23. Rico, J.A.P.; Sauer, I.L. A review of Brazilian biodiesel experiences. Renew. Sust. Energy Rev. 2015, 45, 513-529. [CrossRef]

24. Miranda, A.C.; da Silva Filho, S.C.; Tambourgi, E.B.; CurveloSantana, J.C.; Vanalle, R.M.; Guerhardt, F. Analysis of the costs and logistics of biodiesel production from used cooking oil in the metropolitan region of Campinas (Brazil). Renew. Sust. Energy Rev. 2018, 88, 373-379. [CrossRef]

25. Da Silva, S.C.; Miranda, A.C.; Silva, T.A.F.; Calarge, F.A.; de Souza, R.R.; Santana, J.C.C.; Tambourgi, E.B. Environmental and technoeconomic considerations on biodiesel production from waste frying oil in Sao Paulo city. J. Clean. Prod. 2018, 183, 1034-1042. [CrossRef]

26. César, A.d.S.; Werderits, D.E.; de Oliveira Saraiva, G.L.; Guabiroba, R.C.d.S. The potential of waste cooking oil as supply for the Brazilian biodiesel chain. Renew. Sust. Energy Rev. 2017, 72, 246-253. [CrossRef]

27. Yang, J.; Fujiwara, T.; Geng, Q. Life cycle assessment of biodiesel fuel production from waste cooking oil in Okayama City. J. Mater. Cycles Waste Manag. 2017, 19, 1457-1467. [CrossRef]

28. Kligerman, D.C.; Bouwer, E.J. Prospects for biodiesel production from algae-based wastewater treatment in Brazil: A review. Renew. Sust. Energy Rev. 2015, 52, 1834-1846. [CrossRef]

29. Xu, Y.-J.; Li, G.-X.; Sun, Z.-Y. Development of biodiesel industry in China: Upon the terms of production and consumption. Renew. Sust. Energy Rev. 2016, 54, 318-330. [CrossRef]

30. Sun, J.; Xiong, X.; Wang, M.; Du, H.; Li, J.; Zhou, D.; Zuo, J. Microalgae biodiesel production in China: A preliminary economic analysis. Renew. Sust. Energy Rev. 2019, 104, 296-306. [CrossRef]

31. Chen, J.; Li, J.; Dong, W.; Zhang, X.; Tyagi, R.D.; Drogui, P.; Surampalli, R.Y. The potential of microalgae in biodiesel production. Renew. Sust. Energy Rev. 2018, 90, 336-346. [CrossRef]

32. Dey, S.; Reang, N.M.; Das, P.K.; Deb, M. A comprehensive study on prospects of economy, environment, and efficiency of palm oil biodiesel as a renewable fuel. J. Clean. Prod. 2020, 124981. [CrossRef]

33. Van Noordwijk, M.; Khasanah, N.; Dewi, S. Can intensification reduce emission intensity of biofuel through optimized fertilizer use? Theory and the case of oil palm in Indonesia. Glob. Chang. Biol. Bioenergy 2017, 9, 940-952. [CrossRef]

34. Yusoff, M.; Zulkifli, N.W.M.; Sukiman, N.L.; Chyuan, O.H.; Hassan, M.H.; Hasnul, M.H.; Zulkifli, M.S.A.; Abbas, M.M.; Zakaria, M.Z. Sustainability of Palm Biodiesel in Transportation: A Review on Biofuel Standard, Policy and International Collaboration Between Malaysia and Colombia. Bioenergy Res. 2020. [CrossRef] [PubMed]

35. Zailani, S.; Iranmanesh, M.; Sunghyup, S.H.; Mohd Helmi, A. Barriers of Biodiesel Adoption by Transportation Companies: A Case of Malaysian Transportation Industry. Sustainability 2019, 11, 931. [CrossRef]

36. Faurani Santi, S.; Hendrowati, T.Y.; Sanusi, A. Indonesia Growth of Economics and the Industrialization Biodiesel Based CPO. Int. J. Energy Econ. Policy 2018, 8, 319-334.

37. Harsono, S.S.; Setyobudi, R.H.; Zeemani, T. Biodiesel production from waste fish for zero waste concept in remote area of Eastern of Java, Indonesia. J. Teknol. 2016, 78, 215-219.

38. Ianda, T.F.; Andrade, S.E.; Nogueira, N.A.; Domingos, P.A. Optimizing the Cooperated "Multi-Countries" Biodiesel Production and Consumption in Sub-Saharan Africa. Energies 2020, 13, 4717. [CrossRef]

39. Kgathi, D.L.; Mmopelwa, G.; Chanda, R.; Kashe, K.; Murray-Hudson, M. A review of the sustainability of Jatropha cultivation projects for biodiesel production in southern Africa: Implications for energy policy in Botswana. Agric. Ecosyst. Environ. 2017, 246, 314-324. [CrossRef]

40. Baral, N.R.; Neupane, P.; Ale, B.B.; Quiroz-Arita, C.; Manandhar, S.; Bradley, T.H. Stochastic economic and environmental footprints of biodiesel production from Jatropha curcas Linnaeus in the different federal states of Nepal. Renew. Sust. Energy Rev. 2020, 120. [CrossRef] 
41. Corral, S.; Legna-de la Nuez, D.; Romero-Manrique de Lara, D. Integrated assessment of biofuel production in arid lands: Jatropha cultivation on the island of Fuerteventura. Renew. Sust. Energy Rev. 2015, 52, 41-53. [CrossRef]

42. Castro Gonzáles, N.F. International experiences with the cultivation of Jatropha curcas for biodiesel production. Energy 2016, 112, 1245-1258. [CrossRef]

43. Habibullah, M.; Masjuki, H.H.; Kalam, M.A.; Rahman, S.M.A.; Mofijur, M.; Mobarak, H.M.; Ashraful, A.M. Potential of biodiesel as a renewable energy source in Bangladesh. Renew. Sust. Energy Rev. 2015, 50, 819-834. [CrossRef]

44. Basili, M.; Rossi, M.A. Brassica carinata-derived biodiesel production: Economics, sustainability and policies. The Italian case. J. Clean. Prod. 2018, 191, 40-47. [CrossRef]

45. Đurišić-Mladenović, N.; Kiss, F.; Škrbić, B.; Tomić, M.; Mićić, R.; Predojević, Z. Current state of the biodiesel production and the indigenous feedstock potential in Serbia. Renew. Sust. Energy Rev. 2018, 81, 280-291. [CrossRef]

46. Ganev, E.I.; Dzhelil, Y.R.; Ivanov, B.B.; Vaklieva-Bancheva, N.G.; Kirilova, E.G. Optimal design of a sustainable integrated biodiesel/diesel supply chain using first and second generations bioresources. Chem. Eng. Trans. 2020, 81, 67-72. [CrossRef]

47. Parsons, S.; Raikova, S.; Chuck, C.J. The viability and desirability of replacing palm oil. Nat. Sustain. 2020, 3, 412-418. [CrossRef]

48. Sajid, Z.; Lynch, N. Financial Modelling Strategies for Social Life Cycle Assessment: A Project Appraisal of Biodiesel Production and Sustainability in Newfoundland and Labrador, Canada. Sustainability 2018, 10, 3289. [CrossRef]

49. Nguyen, T.A.; Maeda, Y.; Kuroda, K.; Otsuka, K. Inclusive impact assessment for the sustainability of vegetable oil-based biodiesel-Part II: Sustainability assessment of inedible vegetable oil-based biodiesel in Ha Long Bay, Vietnam. J. Clean. Prod. 2017, 168, 173-188. [CrossRef]

50. Hochman, G.; Tabakis, C. Biofuels and Their Potential in South Korea. Sustainability 2020, 12, 7215. [CrossRef]

51. Živković, S.B.; Veljković, M.V.; Banković-Ilić, I.B.; Krstić, I.M.; Konstantinović, S.S.; Ilić, S.B.; Avramović, J.M.; Stamenković, O.S.; Veljković, V.B. Technological, technical, economic, environmental, social, human health risk, toxicological and policy considerations of biodiesel production and use. Renew. Sust. Energy Rev. 2017, 79, 222-247. [CrossRef]

52. Thomassen, G.; van Dael, M.; Lemmens, B.; van Passel, S. A review of the sustainability of algal-based biorefineries: Towards an integrated assessment framework. Renew. Sust. Energy Rev. 2017, 68, 876-887. [CrossRef]

53. Efroymson, R.A.; Pattullo, M.B.; Mayes, M.A.; Mathews, T.J.; Mandal, S.; Schoenung, S. Exploring the sustainability and sealing mechanisms of unlined ponds for growing algae for fuel and other commodity-scale products. Renew. Sust. Energy Rev. 2020, 121, 109708. [CrossRef]

54. Zhu, L. Biorefinery as a promising approach to promote microalgae industry: An innovative framework. Renew. Sust. Energy Rev. 2015, 41, 1376-1384. [CrossRef]

55. Severo, I.A.; Siqueira, S.F.; Deprá, M.C.; Maroneze, M.M.; Zepka, L.Q.; Jacob-Lopes, E. Biodiesel facilities: What can we address to make biorefineries commercially competitive? Renew. Sust. Energy Rev. 2019, 112, 686-705. [CrossRef]

56. Jacob, A.; Ashok, B.; Alagumalai, A.; Chyuan, O.H.; Le, P.T.K. Critical review on third generation micro algae biodiesel production and its feasibility as future bioenergy for IC engine applications. Energy Convers. Manag. 2020, 113655. [CrossRef]

57. Juneja, A.; Murthy, G.S. Evaluating the potential of renewable diesel production from algae cultured on wastewater: Technoeconomic analysis and life cycle assessment. Aims Energy 2017, 5, 239-257. [CrossRef]

58. Kumar, D.; Singh, B. Algal biorefinery: An integrated approach for sustainable biodiesel production. Biomass Bioenergy 2019, 131. [CrossRef]

59. Pinedo, J.; Prieto, C.V.G.; D'Alessandro, A.A.; Ibáñez, R.; Tonelli, S.; Díaz, M.S.; Irabien, Á. Microalgae biorefinery alternatives and hazard evaluation. Chem. Eng. Res. Des. 2016, 107, 117-125. [CrossRef]

60. Lee, M.; Den, W. Life cycle value analysis for sustainability evaluation of bioenergy products. J. Clean. Prod. 2016, 113, 541-547. [CrossRef]

61. Bravo-Fritz, C.P.; Sáez-Navarrete, C.A.; Herrera-Zeppelin, L.A.; Varas-Concha, F. Multi-scenario energy-economic evaluation for a biorefinery based on microalgae biomass with application of anaerobic digestion. Algal Res. 2016, 16, 292-307. [CrossRef]

62. Doshi, A.; Pascoe, S.; Coglan, L.; Rainey, T.J. Economic and policy issues in the production of algae-based biofuels: A review. Renew. Sust. Energy Rev. 2016, 64, 329-337. [CrossRef]

63. Habib, M.S.; Tayyab, M.; Zahoor, S.; Sarkar, B. Management of animal fat-based biodiesel supply chain under the paradigm of sustainability. Energy Convers. Manag. 2020, 225. [CrossRef]

64. Abomohra, A.E.-F.; Elsayed, M.; Esakkimuthu, S.; El-Sheekh, M.; Hanelt, D. Potential of fat, oil and grease (FOG) for biodiesel production: A critical review on the recent progress and future perspectives. Prog. Energy Combust. Sci. 2020, 81, 100868. [CrossRef]

65. Gaeta-Bernardi, A.; Parente, V. Organic municipal solid waste (MSW) as feedstock for biodiesel production: A financial feasibility analysis. Renew. Energy 2016, 86, 1422-1432. [CrossRef]

66. Gebremariam, S.N.; Marchetti, J.M. Economics of biodiesel production: Review. Energy Convers. Manag. 2018, 168, 74-84. [CrossRef]

67. Chamkalani, A.; Zendehboudi, S.; Rezaei, N.; Hawboldt, K. A critical review on life cycle analysis of algae biodiesel: Current challenges and future prospects. Renew. Sust. Energy Rev. 2020, 134, 110143. [CrossRef]

68. Chowdhury, H.; Loganathan, B. Third-generation biofuels from microalgae: A review. Curr. Opin. Green and Sustain. Chem. 2019, $20,39-44$. [CrossRef] 
69. Dutta, S.; Neto, F.; Coelho, M.C. Microalgae biofuels: A comparative study on techno-economic analysis \& life-cycle assessment. Algal Res. 2016, 20, 44-52. [CrossRef]

70. Granjo, J.; Duarte, B.; Oliveira, N. Soybean biorefinery: Process simulation and analysis. Chem. Eng. Trans. 2015, 45, 583-588. [CrossRef] 